\title{
Forage intake process of goats on a Massai grass pasture with different sward heights ${ }^{1}$
}

\section{Processos de ingestão de forragem por caprinos em pastagem com capim-Massai com diferentes Alturas}

\author{
Marcônio Martins Rodrigues ${ }^{2 *}$; Maria Elizabete de Oliveira3; Tânia Maria Leal ${ }^{4}$; \\ Raniel Lustosa de Moura ${ }^{5}$; Daniel Louçana da Costa Araújo; \\ Maurílio Souza dos Santos ${ }^{6}$; Francelino Neiva Rodrigues ${ }^{7}$; \\ Viviany de Sousa Rodrigues ${ }^{5}$
}

\begin{abstract}
The objective of this study was to evaluate the forage-intake process of goats feeding on Massai grass pastures with different heights $(40,50,60$, and $70 \mathrm{~cm})$. The experimental design was completely randomized, with treatments corresponding to four sward heights with two replicates over time and space. Collected data were related to the forage-intake process and the chemical and morphological composition of the pasture. Grazing trials (45 min) were performed with four Anglo-Nubian crossbred goats. Total forage mass intake, bite mass, and intake rate were expressed in relation to animal weight. Pasture density, forage mass, and leaf blade increased as forage height increased. The chemical composition of forage at the evaluated heights was similar, except for reduced crude protein content at $70-\mathrm{cm}$ height. Bite rate, intake rate, and time per bite had a quadratic relationship with increasing sward height. The greatest intake rate was observed at $54.7 \mathrm{~cm}$ of height, with $0.136 \mathrm{~g} \mathrm{DM} \mathrm{min}^{-1} \mathrm{~kg}^{-1} \mathrm{LW}$. Bite rate exhibited a linear and positive correlation with increase in intake. At the $50-\mathrm{cm}$ height, goats harvested a mass of $3.65 \mathrm{~g} \mathrm{DM} \mathrm{bite}^{-1} \mathrm{~kg}^{-1} \mathrm{LW}$, when they performed 34.5 bites per minute. Adult goats had a greater forage intake on $50-\mathrm{cm}$ high Massai grass pastures because they could obtain a greater bite mass in a shorter time per bite.
\end{abstract}

Key words: Bite mass. Bite rate. Intake rate. Intake.

\section{Resumo}

Objetivou-se avaliar os processos de ingestão de forragem por caprinos em pastagem com capimMassai manejado sob diferentes alturas $(40,50,60$ e $70 \mathrm{~cm})$. O delineamento adotado foi o inteiramente

1 Parte da tese do primeiro autor Universidade Federal do Maranhão.

2 Bolsista DCR FAPEMA/CNPq, Universidade Federal do Maranhão, UFMA, Chapadinha, MA, Brasil. E-mail: marnunes07@ yahoo.com.br

3 Profs. Drs., Departamento de Zootecnia, Universidade Federal do Piauí, UFPI, Teresina, PI, Brasil. E-mail: maeliz@uol.com.br; danielloucana@hotmail.com

${ }^{4}$ Pesquisadora, Embrapa Meio Norte, EMBRAPA, Teresina, PI, Brasil. E-mail: tanialeal13@hotmail.com

${ }^{5}$ Discente do Curso de Doutorado do Programa de Pós-Graduação em Ciência Animal, UFPI, Teresina, PI, Brasil. E-mail: lustosazoo@hotmail.com

${ }^{6}$ Prof. Dr., Curso de Zootecnia, UESPI, Corrente, PI, Brasil. E-mail: maurilio.uespi@gmail.com

7 Prof. M.e, Curso de Agropecuária, IFPI, Paulistana, PI, Brasil. E-mail: f.neiva@hotmail.com

${ }^{8}$ Discente do Curso de Mestrado do Programa de Pós-Graduação em Ciência Animal, UFPI, Teresina, PI, Brasil. E-mail: vivisousarodrigues@hotmail.com

* Author for correspondence 
casualizado. Os tratamentos corresponderam a quatro alturas do dossel com duas repetições no tempo e no espaço. Os dados coletados foram relacionados aos processos de ingestão de forragem e composição química e morfológica do pasto. Foram realizados testes de pastejo de 45 minutos com quatro cabras mestiças da raça Anglonubiana. A massa de forragem total consumida, massa de bocados e a taxa de ingestão foram expressos em relação ao peso dos animais. Com o incremento da altura da forragem houve aumento na densidade do pasto, massa de forragem e lâmina foliar. A composição química da forragem nas alturas avaliadas foi semelhante, com exceção da redução do teor de proteína bruta aos $70 \mathrm{~cm}$. A taxa de bocado, taxa de ingestão e tempo por bocado apresentou relação quadrática com o aumento da altura. A maior taxa de ingestão foi observada aos 54,7 cm de altura, com 0,136 g MS min ${ }^{-1}$ $\mathrm{kg}^{-1}$ de PC. A massa de bocado apresentou relação linear e positiva com o aumento da altura. Aos 50 $\mathrm{cm}$ as cabras colheram uma massa de 3,65 g MS bocado $\mathrm{gg}^{-1} \mathrm{PC}$, quando realizavam 34,5 bocados por minuto. No pasto de capim-massai aos $50 \mathrm{~cm}$ ocorre maior consumo de forragem por cabras adultas, pois os animais conseguem obter uma massa maior do bocado em menor tempo por bocado.

Palavras-chave: Consumo. Massa do bocado. Taxa de ingestão. Taxa de bocado.

\section{Introduction}

The use of cultivated pasture for goats is a recent technique, because most goats feed on native pastures, especially in northeastern Brazil. An understanding of animal-pasture interactions for these small ruminants on a monoculture is of importance to the determination of management strategies that will provide greatest intake. Little information is available concerning how these small ruminants behave and feed on cultivated pastures with different structures. Understanding the behavior of these animals, classified as intermediate selectors (HOFFMAN, 1989), on cultivated pastures, will allow us to define a management practice that potentiates animal performance (ROMAN et al., 2007).

The vertical and horizontal structure of the pasture, expressed mainly by the available forage mass, height, and density of dry matter, has been studied regarding its influence on forage intake (PINTO et al., 2007). Among structural variables for pastures, height is one of the main tools for pasture management because it is associated with the available forage, as well as how the animals access food (SILVA et al., 2009).

Different pasture heights cause variation in the performance of an animal, resulting from a greater or lesser ability to ingest the forage (CARVALHO et al., 2007). Increased pasture height should mean a greater amount of food could be ingested, because, in theory, the taller the pasture, the greater the opportunity an animal has to meet its intake requirements. This is especially true when the pasture has morphological characteristics that contribute to adequate forage harvesting, such as a large number of leaves, which are the most digestible and preferred part by animals. However, lower grazing heights may lead animals to reduce their intake, because the depth of their bite is lower, and consequently, the bite mass captured will also be smaller, which will affect the forage intake rate of the animals (DECRUYENAERE et al., 2009).

Components of ingestive behavior, such as bite rate, bite mass, and forage-intake rate of animals, can change when animals are subjected to different vegetative structures (GONG et al., 1996; OLIVEIRA NETO et al., 2013). Animals change the parameters of their ingestive process in an attempt to meet their intake requirements, because variables such as bite mass and forage-intake rate differ according to pasture structure, especially height. Changes in pasture height might affect the time required to grasp and chew the food, which consequently alters intake of forage (MACEDO et al., 2015).

It is necessary to determine the pasture structures that provide adequate intake by goats. The goals would be to optimize available forage 
and avoid losses caused by rejection of undesirable parts by animals (e.g., stems) or by reduction of intake because of increased time taken during the manipulation process, and ultimately to achieve good animal performance. Therefore, the objective of this study was to evaluate the forage-intake process in goats on Massai grass pastures with different sward heights.

\section{Material and Methods}

The experiment was conducted from November 2011 to February 2012, in the experimental area of Embrapa Meio-Norte, located in the municipality of Teresina/PI, Brazil $\left(5^{\circ} 6^{\prime} 18^{\prime \prime}\right.$ latitude, 42 48'12" longitude). The soil was a yellow Latisol, according to the Embrapa (2006) classification, with the following chemical properties: $\mathrm{pH}$ in water $6.3, \mathrm{Ca}+\mathrm{Mg} 2.5 \mathrm{cmol}_{\mathrm{c}} \mathrm{dm}^{-}$ ${ }^{3}, \mathrm{~K} 0.11 \mathrm{cmol}_{\mathrm{c}} \mathrm{dm}^{-3}$, sum of bases $2.5 \mathrm{cmol}_{\mathrm{c}} \mathrm{dm}^{-3}$, $\mathrm{CEC}$ at $\mathrm{pH} 77.1 \mathrm{cmol}_{\mathrm{c}} \mathrm{dm}^{-3}$, base saturation $41 \%$, and $\mathrm{OM} 16.60 \mathrm{~g} \mathrm{~kg}^{-1}$. According to the Köppen classification, the climate in Teresina was tropical rainy $\mathrm{Aw}^{\prime}$ (megathermal), with dry winters and rainy summers. Maximum, minimum, and average daily temperatures were $34.2,22.9$, and $34^{\circ} \mathrm{C}$, respectively. The relative air humidity varied from 75 to $83 \%$, and the accumulated rainfall during the period was $446.5 \mathrm{~mm}$ (Figure 1).

Figure 1. Precipitation $(\mathrm{mm})$, temperature $\left({ }^{\circ} \mathrm{C}\right)$, and relative air humidity $(\%)$ during experimental period
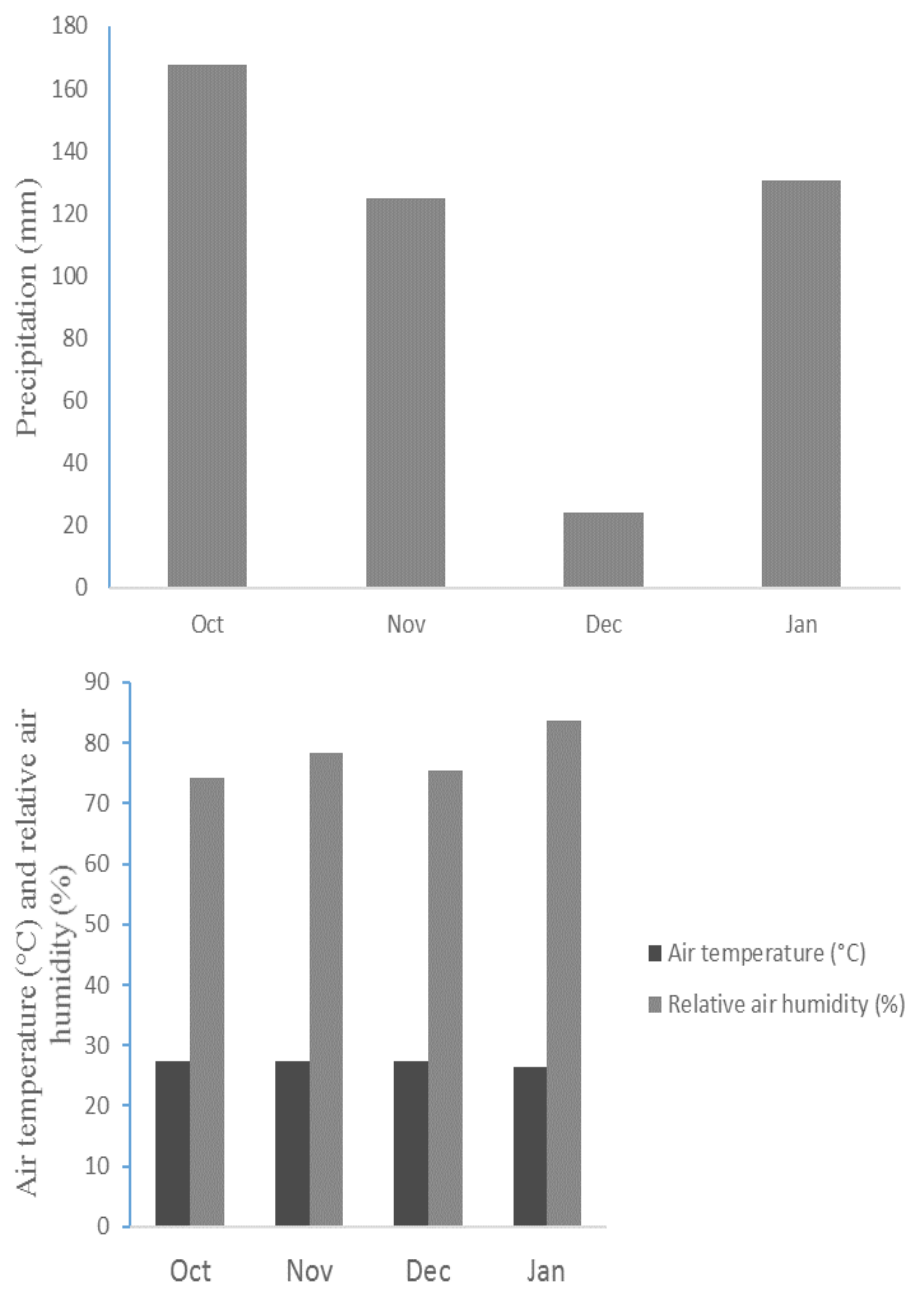
The Massai grass pasture was planted in a 0.34 ha area in 2010. The soil was analyzed before the establishment of the pasture, and based on the results fertilization was applied only once, with 100-120-50 kg of N-P-K ha-1.

Eight $170-\mathrm{m}^{2}$ paddocks were used. A plotleveling cut was initially made at $20 \mathrm{~cm}$ above the soil, and evaluations were conducted when the pastures reached heights of 40,50,60, and $70 \mathrm{~cm}$. The time of the evaluations was determined by the average of 30 measurements of height taken in the pasture every two days, using a graded ruler. The average was allowed to vary within $5 \%$ of the defined values.

Grazing trials (45 min) were performed with four Anglo-Nubian goats. Dry goats with an average live weight of $\pm 30 \mathrm{~kg}$ (0.42) were used. The forage allowance during the experimental period was 9.9, $9.6,10.7$, and $16.8 \%$ for the heights of $40,50,60$, and $70 \mathrm{~cm}$, respectively.

The forage mass pre-grazing was measured by casting two $0.50 \mathrm{~m}^{2}$ frames randomly over each paddock and cutting the forage within the frame at $20 \mathrm{~cm}$ above the soil level. Pasture height was measured using a graduated ruler and 30 readings were taken per paddock.

A representative aliquot of the harvested samples was collected to determine the pre-grazing forage mass for evaluation of the morphological components of the pasture. This aliquot was separated into the leaf blade, pseudostem (stem + sheath), and dead-material fractions, which were weighed and dried in a forced air-circulation oven at $65^{\circ} \mathrm{C}$ for $72 \mathrm{~h}$. The green forage mass was expressed in $\mathrm{kg} \mathrm{DM} \mathrm{ha}{ }^{-1}$.

The chemical composition of the pasture was obtained from samples simulating the grazing activity of the animals. The crude protein (CP) and mineral matter (MM) contents were determined using the methodology proposed by the AOAC (2012). The NDF and ADF contents were determined following the method of Van Soest et al. (1991). The total digestible nutrient (TDN) level was estimated according to Cappele et al. (2001). In vitro dry matter digestibility was determined according to the technique of Tilley and Terry (1963) in an in vitro incubator developed by Tecnal.

The ingestion processes were determined by double sampling during 45-min grazing tests, according to Penning and Hooper (1985). The night before the evaluations, goats were gathered and deprived of solids and liquids. Prior to the beginning of data collection, the goats were equipped with feces and urine collectors, weighed, and taken to the paddocks. The goats were grouped in two pairs. The first pair (animals A and B) remained contained near the paddock and unable to consume water or feed, to allow the evaluation of metabolic losses, which were determined by variation in weight during $45 \mathrm{~min}$. The second pair (animals $\mathrm{C}$ and D) was subjected to a 45-min grazing trial, monitored by four evaluators that worked in pairs. Each pair evaluated one animal on the pasture and recorded the number of bites and feeding time using counters and stopwatches.

At the end of the 45 min, animals C and D were weighed (holding the feces and urine collectors) to determine the weight difference between the time they entered and exited the pasture. Animals A and $\mathrm{B}$, which were on standby, were also weighed and moved to the second grazing session, during which the same procedures were repeated while animals $C$ and D were contained.

Forage intake (I) was calculated by the equation $\mathrm{I}=\left(\mathrm{W}_{2}+\mathrm{F}+\mathrm{U}+\mathrm{MWL}\right)-\mathrm{W}_{1}$, where $\mathrm{W}_{1}$ and $\mathrm{W}_{2}$ = weight of the animals before and after grazing, respectively, $F=$ weight of feces, $U=$ weight of urine, and $\mathrm{MWL}=$ metabolic-weight loss.

The ingestive behavior of the grazing goats was determined by the methodology of Palhano et al. (2007), according to the 45-min-grazing testing protocol, in which bite rate (bites $\mathrm{min}^{-1}$ ), time per bite $\left(\mathrm{s}\right.$ bite $\left.{ }^{-1}\right)$, total forage-mass intake $(\mathrm{g}$ DM kg-1 LW), bite mass (mg DM bite-1 $\mathrm{kg}^{-1} \mathrm{LW}$ ), and intake 
rate $\left(\mathrm{g} \mathrm{DM}^{-1} \mathrm{~min}^{-1} \mathrm{~kg} \mathrm{LW}\right)$ were evaluated. The total forage-mass intake, bite mass, and intake rate were expressed in relation to the weight of the goats.

Total forage mass intake was calculated as the difference in the weight of each animal between the two weighing sessions, plus the respective metabolic losses. The bite mass was the ratio between foragemass intake and the number of bites during the grazing periods. Intake rate was the ratio between forage-mass intake per live weight and the effective time for intake.

The statistical design was completely randomized, with four pasture heights and two replicates over time and space. Linear regressions were used in the analysis of pasture characteristics, whereas for analyses of ingestive processes, linear and polynomial regressions to the second degree and Pearson's correlation analyses were performed using the SAS (2002) statistical software.

\section{Results and Discussion}

The pasture heights of $40,50,60$, and $70 \mathrm{~cm}$ corresponded to the $18,22,30$, and 48 days of regrowth and influenced the forage mass and pasture structure (Table 1). The greatest forage and leafblade masses and pasture and leaf-blade densities were observed in the $70-\mathrm{cm}$ pasture $(3,152.6$ and 2,400.4 kg DM ha-1; 44.59 and $33.95 \mathrm{~kg} \mathrm{DM}^{-1} \mathrm{~cm}^{-1}$ ha, respectively). Leaf mass predominated and an absence of stem was detected in the pastures with 40 and $60 \mathrm{~cm}$ heights. At $70 \mathrm{~cm}$, stem was present, but the leaf:stem ratio of 2.1 indicated a high proportion of the leaf component in the pasture. Ribeiro et al. (2012), under similar environmental conditions, did not observe the presence of stem and senescent material in Tanzania grass, which is in the same genus as Massai grass, at 30 to $50 \mathrm{~cm}$ height. This was similar to the characteristics observed in Massai grass at 40 to $60 \mathrm{~cm}$.

Table 1. Structural and chemical characteristics of the Massai grass pasture with different sward heights.

\begin{tabular}{|c|c|c|c|c|c|c|}
\hline \multirow{2}{*}{$\begin{array}{l}\text { Sward structural and } \\
\text { chemical characteristics }\end{array}$} & \multicolumn{4}{|c|}{ Sward height $(\mathrm{cm})$} & \multirow{2}{*}{ Regression equation } & \multirow{2}{*}{$\mathrm{R}^{2}$} \\
\hline & 40 & 50 & 60 & 70 & & \\
\hline Actual entry height $(\mathrm{cm})$ & 39.9 & 49.3 & 57.7 & 70.7 & & \\
\hline Actual exit height $(\mathrm{cm})$ & 31.8 & 39.0 & 43.2 & 55.9 & & \\
\hline $\begin{array}{l}\text { Forage mass } \\
\left(\mathrm{kg} \mathrm{DM} \mathrm{ha}^{-1}\right)\end{array}$ & 701.7 & $1,189.4$ & $1,774.1$ & $3,152.6$ & $\hat{Y}=-2661+79.37 * x$ & 0.93 \\
\hline $\begin{array}{l}\text { Leaf blade mass } \\
\left(\mathrm{kg} \mathrm{DM} \mathrm{ha}^{-1}\right)\end{array}$ & 701.7 & $1,189.4$ & $1,774.1$ & $2,400.4$ & $\hat{y}=-1608+56.80 * x$ & 0.99 \\
\hline $\begin{array}{l}\text { Pasture density } \\
\left(\mathrm{kg} \mathrm{DM}^{-1} \mathrm{~cm}^{-1} \mathrm{ha}\right)\end{array}$ & 17.58 & 24.12 & 30.74 & 44.59 & $\hat{y}=-18.95+0.87 * x$ & 0.96 \\
\hline $\begin{array}{l}\text { Leaf blade density } \\
\left(\mathrm{kg} \mathrm{DM}^{-1} \mathrm{~cm}^{-1} \mathrm{ha}\right)\end{array}$ & 17.58 & 24.12 & 30.74 & 33.95 & $\hat{y}=-4.05+0.55^{*} x$ & 0.97 \\
\hline Leaf/stem ratio & - & - & - & 2.1 & & \\
\hline $\mathrm{CP}(\%)$ & 10.5 & 12.2 & 10.4 & 7.5 & $\begin{array}{c}\hat{y}=-16.4327+1.1272 x- \\
0.0112 * x^{2}\end{array}$ & 0.97 \\
\hline NDF (\%) & 74.5 & 75.0 & 72.9 & 74.2 & $\bar{y}=74.15$ & - \\
\hline $\operatorname{ADF}(\%)$ & 39.4 & 37.5 & 38.1 & 39.0 & $\bar{y}=38.50$ & 0.89 \\
\hline IVOMD (\%) & 58.06 & 57.27 & 56.72 & 56.17 & $\hat{y}=60.47-0.0622 * x$ & 0.99 \\
\hline $\mathrm{TDN} *(\%)$ & 53.39 & 53.07 & 52.42 & 53.12 & $\overline{\mathrm{y}}=53.00$ & - \\
\hline
\end{tabular}

*Values estimated by the formula of Cappele et al. (2001). 
The CP contents displayed quadratic behavior $(\mathrm{P}<0.05)$ (Table 1). From 40 to $60 \mathrm{~cm}$ of height, the pasture exhibited an average of $11 \% \mathrm{CP}$ (Table 1), corresponding to $78.2 \mathrm{~kg} \mathrm{CP} \mathrm{ha}{ }^{-1}$. Leaf blade mass at $70 \mathrm{~cm}$, provided lower protein intake, but higher yield, and resulted in $180.0 \mathrm{~kg} \mathrm{CP} \mathrm{ha}{ }^{-1}$. The quadratic behavior of CP can be explained by the composition of the pasture. At $40 \mathrm{~cm}$ of height, the pasture had greener leaves, which expanded after the plot-leveling mowing, unlike that observed at 50 $\mathrm{cm}$, at which time the pasture had younger leaves from the regrowth of basal tillers. New leaves have a greater crude protein level than older leaves (SANTOS et al., 2009).

The NDF and ADF levels of the Massai grass did not conform to the equation (Table 1), with mean values of $\bar{y}=74.15$ and $\bar{y}=38.50 \%$, respectively. This was because the samples collected for the pasture for chemical analyses were obtained by evaluators, who simulated animal grazing, and were composed only of leaves from the upper part of the pasture. They did not contain stems even at the greatest pasture height $(70 \mathrm{~cm})$. The total digestible nutrients (TDN) of the Massai grass between 40 and $70 \mathrm{~cm}$ did not differ $(\mathrm{P}>0.05)$ (Table 1$)$. The in vitro $\mathrm{OM}$ digestibility values were similar to those reported in the literature for tropical forage grasses, between 40 and $60 \%$. These results occurred because of non-limiting FDA levels and variations in PB (PACIULLO et al., 2007; VARGAS JÚNIOR et al., 2013). The average TDN level of 53\% (Table 1 ) is in agreement with values obtained from other tropical grasses (BENETT et al., 2008; OLMEDO et al., 2011). Although the NDF and ADF contents did not differ and the cell wall provides energy to the ruminants, the amount of energy available at the different heights did not limit intake because the Massai grass pastures with 40 to $70 \mathrm{~cm}$ of height exhibited similar TDN.

The bite rate exhibited a quadratic behavior $(\mathrm{P}<$ 0.05 ) according to the pasture sward height (Figure 2a). The estimated bite rate increased up to 48.9 $\mathrm{cm}$, with 34.5 bites $\mathrm{min}^{-1}$, and then decreased as the sward height increased. From 40 to $48.9 \mathrm{~cm}$, there was a bite rate increase of 1.3 bites $\mathrm{min}^{-1}$. At the lowest heights, the animals tried to compensate for the lower leaf-blade mass (Table 1) and lower bite depth by increasing their bite rate. This behavior was also observed by Camargo et al. (2012), who evaluated the bite rate of lambs on ryegrass pastures.

Time per bite (Figure 2b), which is the inverse of the bite rate, exhibited a decrease up to $51.7 \mathrm{~cm}$, approximate to the greatest bite rate $(48.9 \mathrm{~cm})$. From this point, it increased with sward height. This may be a result of the greater forage mass ingested per bite (Figure 2c) with increased sward height. Thus, the animal took longer to form and manipulate the bite when on taller pastures.

Bite mass increased $(\mathrm{P}<0.02275)$ with increasing pasture height (Figure 2d), which resulted in a longer time per bite (Figure $2 b$ ). When the sward height and leaf-blade mass were lower, bite mass was reduced (Figure 2d); thus, animals required a longer time for chewing, which led to a greater bite rate to compensate for forage intake. Lower bite rates by goats grazing tussock grasses were observed by some authors (RIBEIRO et al., 2012; RODRIGUES et al., 2013; VELOSO FILHO et al., 2013), indicating that this growth habit limits the forage-intake process by these animals.

The ratio between bite mass (Figure 2d) and sward height $(\mathrm{P}<0.0275)$ varied from $3.03 \mathrm{~g} \mathrm{DM}$ bite $\mathrm{kg}^{-1} \mathrm{LW}$ (or $0.091 \mathrm{~g} \mathrm{DM}$ bite $^{-1}$ animal $^{-1}$ ) to 3.84 g DM bite $\mathrm{kg}^{-1} \mathrm{LW}$ (or $0.116 \mathrm{~g} \mathrm{DM}^{-1}$ animal $^{-1}$ ) from the lowest to highest evaluated heights, respectively. Greater bite masses were obtained at the greatest height, indicating greater forage and leaf-blade masses (Table 1).

Height was a decisive factor in bite mass (Figure 2d). Positive responses were observed in bite mass and bite time at the greatest sward heights (Figure $2 b$ ), with a consequent reduction in bite rate (Figure 2a). This fact points to a growing deficiency of forage grasping with increase in sward structure. However, there was an increase in intake rate (Figure 2c) and 
in the total forage mass intake (Figure 2e) for the reduction, probably because of the difficulty in heights of 54.7 and $52.5 \mathrm{~cm}$, respectively, with later manipulating the bite as pasture height increased.

Figure 2. a) bite rate (bites $\left.\min ^{-1}\right)$, b) time per bite (s), c) intake rate $\left.\left(\mathrm{g} \mathrm{DM} \mathrm{min}{ }^{-1} \mathrm{~kg}^{-1} \mathrm{LW}\right), \mathrm{d}\right)$ bite mass $(\mathrm{g} \mathrm{DM}$ bite-1 $\mathrm{kg}^{-1} \mathrm{LW}$ ), and e) total forage-mass intake ( $\mathrm{g} \mathrm{DM} \mathrm{kg}^{-1} \mathrm{LW}$ ) by goats on Massai grass pastures with different sward heights.

a)
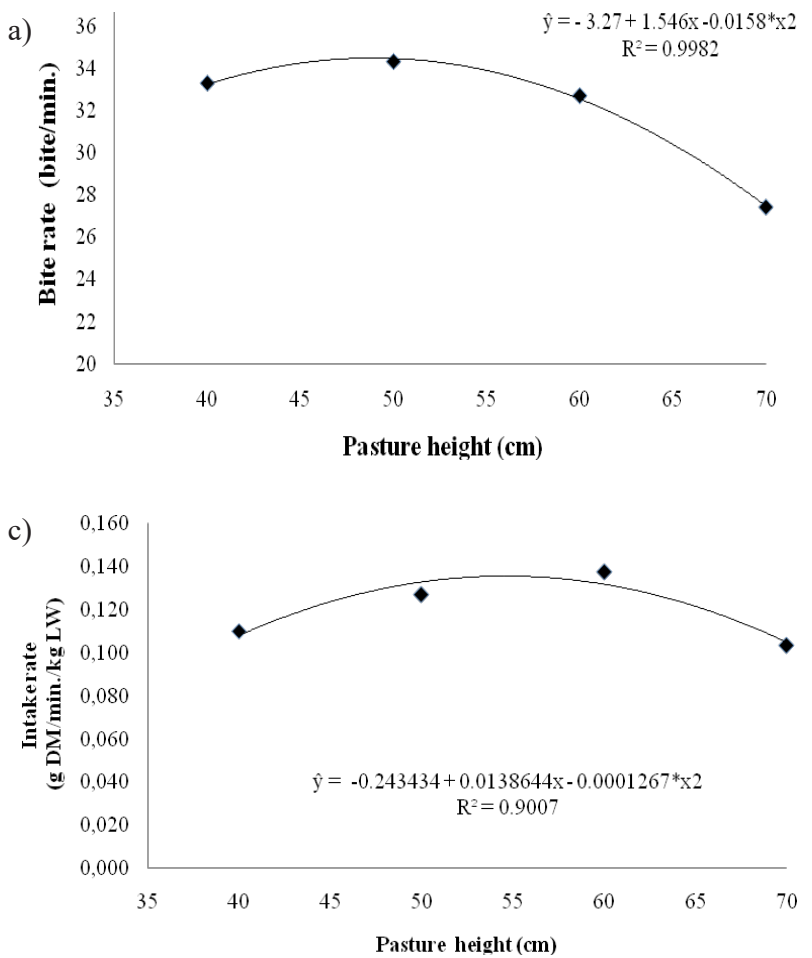

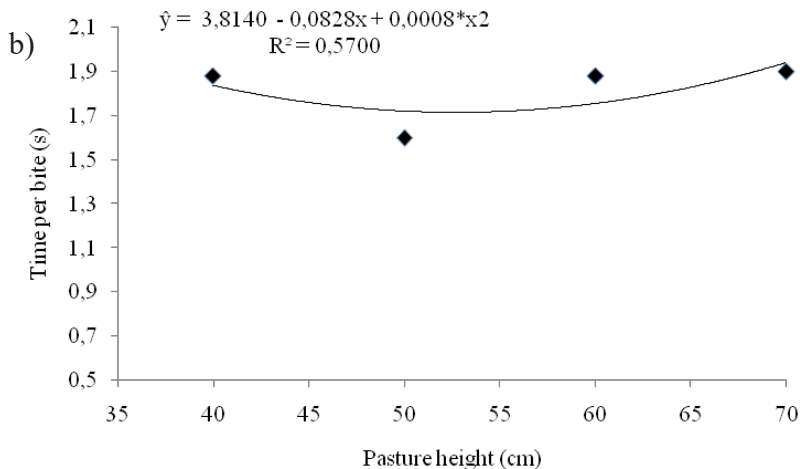

d)

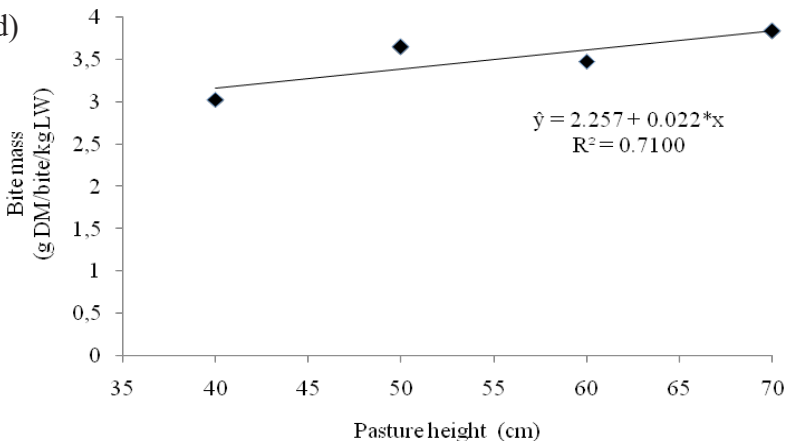

e)

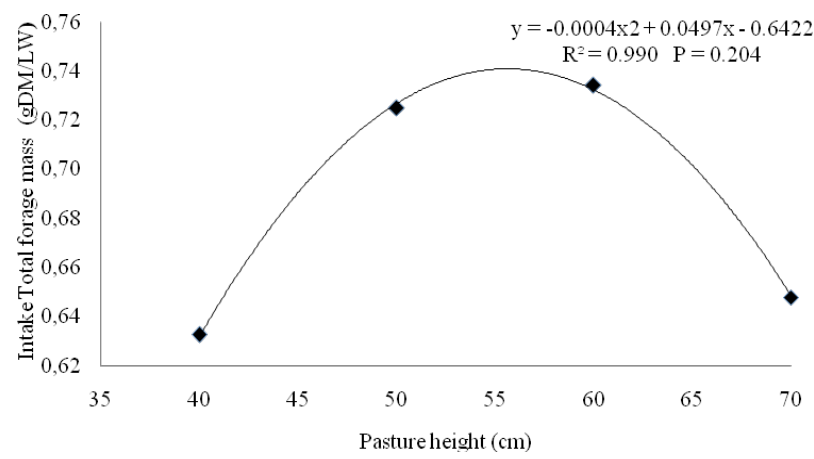

The quadratic behavior between intake and pasture height, with maximum intake of $0.136 \mathrm{~g}$ DM min ${ }^{-1} \mathrm{~kg}^{-1} \mathrm{LW}$ (Figure 2c), was likely influenced by the chemical composition of the pasture because the maximum CP content (11.9\%) occurred at 50.3 $\mathrm{cm}$ of height (Table 1). The decrease in intake rate at heights greater than $54.7 \mathrm{~cm}$ was likely caused by the greater pasture height, which resulted in more time spent per bite (Figure 2b).

Forage grasping (time per bite) influenced the reduction of forage intake speed by Anglo-Nubian goats. Intake rate is related to grasping and chewing 
of forage (WOODWARD, 1997), considering that the increase in chewing time is linked to dietary fiber content, which in the current study did not differ among pasture heights. In taller pastures, longer leaves are difficult grasp by goats. In addition, they promote larger bites, which require longer chewing time for better swallowing. In this situation, more time for the manipulative process consequently reduced intake rate.

The relationship between forage intake and pasture height was quadratic. The estimated maximum intake of $0.70 \mathrm{~g} \mathrm{DM} \mathrm{kg}^{-1} \mathrm{LW}$ was reached at $52.5 \mathrm{~cm}$ (Figure 2e). At this height, the pasture was composed of leaf blades only (Table 1), which demonstrated that the factor with the greatest contribution to increased intake was pasture height. At the heights of 40 and $70 \mathrm{~cm}$, lower forage mass intake was observed (Figure 2c). In the two cases, height was most likely the main limiting factor. At $40 \mathrm{~cm}$, it negatively affected bite depth, and at 70 $\mathrm{cm}$, the higher forage allowed the animals to seeking new grazing sites instead of deepening their bite.

The results obtained for other variables of the ingestive process, intake rate, bite rate, and bite mass, indicated that the intake by goats on Massai grass pasture with $52.5 \mathrm{~cm}$ of height is conditioned by the combination between height and density. A similar behavior at $50 \mathrm{~cm}\left(28 \mathrm{~g} \mathrm{DM} \mathrm{kg}^{-1} \mathrm{LW}\right)$ was obtained in a study conducted with goats in a subhumid region (RIBEIRO et al., 2012), wherein the lowest intake (18 $\left.\mathrm{g} \mathrm{DM} \mathrm{kg}^{-1} \mathrm{LW}\right)$ was found at 30 $\mathrm{cm}$ and the greatest $\left(23 \mathrm{~g} \mathrm{DM} \mathrm{kg}^{-1} \mathrm{LW}\right)$ at $90 \mathrm{~cm}$.

Bite mass exhibited a positive correlation with intake rate $(0.81)$ and with the forage-mass intake (0.82). That is, at $52.5 \mathrm{~cm}$ of height, the pasture structure provided an appropriate bite mass for goats and also allowed a greater intake rate (54.7 g DM $\mathrm{min}^{-1} \mathrm{~kg}^{-1} \mathrm{LW}$ ) with less time spent per bite $\left(1.67 \mathrm{~s} \mathrm{bite}^{-1}\right)$.

An increase in bite mass with the increase in the pasture height provided an elevation in the intake rate until $60 \mathrm{~cm}$. From this point onwards, bite mass continued to increase linearly, whereas the intake rate and bite rate began to decrease. This behavior can be explained by the increase in pasture height, where the animal attempts to increase its bite mass to compensate for the reduction of forage intake and bite rate (Figures $2 \mathrm{c}$ and $2 \mathrm{a}$ ), probably caused by the difficulty in grasping forage and manipulating bites. With the increase in pasture height, the goats increased the bite mass and time per bite (Figures $2 \mathrm{~d}$ and $2 \mathrm{~b}$ )

The greatest estimated intake occurred at the height of $52.5 \mathrm{~cm}$; however, there was no correlation between intake and bite rate $(P=0.2643)$ even though the greatest bite rate occurred at $48.9 \mathrm{~cm}$ of height. The change in the sward structure with the increase in the masses of forage $(P=0.1189)$ and leaf blade $(\mathrm{P}=0.1207)$ also did not affect bite rate among the heights. However, the time per bite was negatively correlated $(-0.72 ; \mathrm{P}=0.0002)$ with bite rate. When the pasture was taller, the goats reduced their bite rate and increased the time per bite by increasing the time spent grasping and chewing.

\section{Conclusions}

The height of Massai grass pastures determined the ingestive-behavior patterns of Anglo-Nubian goats.

The greatest forage intake was observed at approximately $50 \mathrm{~cm}$ of height because goats obtain an appropriate bite mass with less time spent per bite, resulting in greater forage intake.

\section{References}

ASSOCIATION OF OFFICIAL ANALYTICAL CHEMISTS - AOAC. Official methods of analysis. $19^{\text {th }}$ ed. Arlington: AOAC International, 2012.

BENETT, C. G. S.; BUZETTI, S.; SILVA, K. S.; BERGAMASCHINE, A. F.; FABRÍCIO, J. A. Produtividade e composição bomatológica do capimmarandu a fontes e doses de nitrogênio. Ciência e Agrotecnologia, Lavras, v. 32, n. 5, p. 1629-1636, 2008. 
CAMARGO, D. G.; ROCHA, M. G.; SILVA, J. H. S.; GLIENKE, C. L.; CONFORTIN, A. C. C.; MACHADO, J. M. Características da ingestão de forragens por cordeiros nos estádios fenológicos da pastagem de azevém. Arquivo Brasileiro de Medicina Veterinária e Zootecnia, Belo Horizonte, v. 46, n. 2, p. 403-410, 2012.

CAPPELE, E. R.; VALADARES FILHO, S. C.; SILVA, J. F. C.; CECON, P. R. Estimativa do valor energético a partir de características químicas e bromatológicas dos alimentos. Revista Brasileira de Zootecnia, Viçosa, MG, v. 30, n. 6, p. 1837-1856, 2001.

CARVAlHO, P. C. F.; SANTOS, D. T.; NEVES, F. P. Oferta de forragem como condicionadora da estrutura do pasto e o desempenho animal. In: DALL'AGNOL, M.; NANBINGER, C.; SANTANA, D. M.; SANTOS, R. J. (Org.). Sustentabilidade produtiva do bioma pampa. Porto Alegre: Gráfica Metrópole Ltda, 2007. p. 23-60.

DECRUYENAERE, V.; BULDGEN, A.; STILMANT, D. Factors affecting intake by grazing ruminants and related quantification methods: a review. Biotechnology Agronomy and Society and. Enviromente, Amsterdam, v. 13, n. 4, p. 559-573, 2009.

\section{EMPRESA BRASILEIRADE PESQUISA} AGROPECUÁRIA - EMBRAPA. Centro Nacional de Pesquisa de Solos. Sistema Brasileiro de Classificação de Solos. 2. ed. Rio de Janeiro: Serviço de Produção de Informação, 2006. 306 p.

GONG, Y.; LAMBERT, M. G.; HODGSON, J. Effects of contrasting swards heights within forage species on short-term ingestive behavior of sheep and goats grazing grasses and legumes. New Zealand Journal of Agricultural Research, Osaka, v. 39, n. 1, p. 83-93, 1996.

HOFFMAN, R. R. Evolutionary steps of ecophysiological adaptation and diversification of ruminants: a comparative view of their digestive system. Oecologia, Berlim, v. 78, n. 4, p. 443-457, 1989.

MACEDO, E. O.; OLIVEIRA, M. E.; SILVA, P. C.; RIBEIRO, A. M.; OLIVEIRA, G. L.; ANDRADE, A. C.; RODRIGUES, M. M. Consumo e comportamento ingestivo de cabras em pasto de capim-marandu. Semina: Ciências Agrárias, Londrina, v. 36, n. 3, p. 2175-2184, 2015 .

OLIVEIRA NETO, R. A.; SILVA, J. H. S.; ROCHA, M. G.; PÖSTER, L.; SICHONAMY, M. J. O.; BISCAINO, L. L.; SANTOS, F. A.; DIFANTE, M. V. B. Ingestive behaviour, performance and forage intake by beef heifers on tropical pasture systems. Revista Brasileira de Zootecnia, Viçosa, MG, v. 42, n. 8, p. 549-558, 2013.
OLMEDO, D. O.; BARCELLOS, J. O. J.; CANELLAS, L. C.; VELHO, M. M. S.; PANIAGUA, P.; HORITA, I.; TAROUCO, J. U. Desempenho e característica da carcaça de novilhas terminados em pastejo rotacionado ou em confinamento. Arquivo Brasileiro de Medicina Veterinária e Zootecnia, Belo Horizonte, v. 63, n. 2, p. 348-355, 2011.

PACIULlO, D. S. C.; CARVALHO, C. A. B.; AROEIRA, L. J. M.; MORENZ, M. J. F.; LOPES, F. C. F.; ROSSIELLO, R. O. P. Morfofisiologia e valor nutritivo do capim-braquiária sob sombreamento natural e a sol pleno. Pesquisa Agropecuária Brasileira, Brasília, v. 42 , n. 4, p. $573-579,2007$.

PALHANO, A. L.; CARVALHO, P. C. F.; DITTRICH, J. R.; MORAES, A.; SILVA, S. C.; MONTEIRO, A. A. G. Características do processo de ingestão de forragem por novilhas holandesas em pastagens de capim-monbaça. Revista Brasileira de Zootecnia, Viçosa, MG, v. 36, n. 4, p. 1014-1021, 2007.

PENNING, P. D.; HOOPER, G. E. N. A evaluation of the use of short-term weight changes in grazing sheep for estimating herbage intake. Grass and Forage Science, London, v. 40, n. 1, p. 79-84, 1985.

PINTO, C. E.; CARVALHO, P. C. F.; FRIZZON, A.; FONTOURA JÚNIOR, J. A. S.; ROCHA, R.; NANBINGER, C. Comportamento ingestivo de novilhos em pastagem nativa no Rio Grande do Sul. Revista Brasileira de Zootecnia, Viçosa, MG, v. 36, n. 2, p. 319327, 2007.

RIBEIRO, A. M.; OLIVEIRA, M. E.; CARVALHO, P. S.; RUFINO, M. O. A.; RODRIGUES, M. M.; SANTOS, M. S. Canopy characteristics, animal behavior and forage intake by goats grazing on Tanzania-grass pasture with different heights. Acta Scientiarum. Animal Sciences, Maringá, v. 34, n. 4, p. 371-378, 2012.

RODRIGUES, M. M.; OLIVEIRA, M. E.; MOURA, R. L.; RUFINO, M. O. A.; SILVA, W. K.A.; NASCIMENTO, M. P. S. C. B. Forage intake and behavior of goats on Tanzania-grass pasture at two regrowth ages. Acta Scientiarum. Animal Sciences, Maringá, v. 35, n. 1, p. 37-41, 2013.

ROMAN, J.; ROCHA, M. G. da; PIRES, C. C.; ELEJAIDE, D. A. G.; KLOSS, M. G.; OLIVEIRA NETO, R. A. Comportamento ingestivo e desempenho de ovinos em pastagem de azévem de forragem anual (Lolium multiflorum Lam.) com diferentes massas de forragem. Revista Brasileira de Zootecnia, Viçosa, MG, v. 36, n. 4, p. 780-788, 2007. 
SANTOS, M. E. R.; FONSECA, D. M.; BALBINO, E. M.; MONNERAT, J. P. I. S.; SILVA, S. P. Capimbraquiária diferido e adubado com nitrogênio: produção e características da forragem. Revista Brasileira de Zootecnia, Viçosa, MG, v. 38, n. 4, p. 650-656, 2009.

SILVA, C. J. A.; DITTRICH, J. R.; MONTEIRO, A. L. G.; MORAES, A.; BARROS, C. S.; OLIVEIRA, E. B. Preferência de caprinos em pastejo: efeito da altura dos dosséis das forrageiras aruana e hemártria. Ciência Animal Brasileira, Goiânia, v. 10, n. 3, p. 698-710, 2009.

STATISTICAL ANALYSIS SYSTEM - SAS. System for Microsoft Windows: release 8.2. Cary: Statistical Analysis System, 2002. CD-ROM.

TILLEY, J. M. A.; TERRY, R. A. A two-stage technique for the in vitro digestion of forage crops. Journal of the British Grassland Society, London, v. 18, n. 2, p. 104111, 1963.
VAN SOEST, P. J.; ROBERTSON, J. B.; LEWIS, B. A. Carbohydrate methodology, metabolism, and nutritional implications in dairy caltle. Journal of Dairy Science, Champaign, v. 74, n. 10, p. 3583-3597, 1991.

VARGAS JÚNIOR, F. M.; SOCORRO, M. M.; SETTI, J. C. A.; PINTO, G. S.; MARTINS, C. F.; COSTA, J. A. A.; MAGRIN, M. M.; CAMILO, F. R.; MONTAGNER, D. B. Disponibilidade e valor nutritivo de gramíneas tropicais sob pastejo com ovinos. Archivos Zootecnia, Cordoba, v. 62, n. 238, p. 293-298, 2013.

VELOSO FILHO, E. S.; RODRIGUES, M. M.; OLIVEIRA, M. E.; RUFINO, M. O. A. Comportamento de caprinos em pastagem de capim- marandu manejado sob lotação rotacionada sob duas idades de rebrotação. Comunicata Scientiae, Bom Jesus, v. 4, n. 3, p. 238-243, 2013.

WOODWARD, S. J. R. Formulae for predicting animals daily intake of pasture and grazing time from bite weight and composition. Livestock Production Science, Amsterdam, v. 52, n. 1, p. 1-10, 1997. 